\title{
Morphology and Development of Odostomia columbiana Dall and Bartsch (Pyramidellidae): Implications for the Evolution of Gastropod Development
}

\author{
RACHEL COLLIN ${ }^{1} *$ AND JOHN B. WISE ${ }^{2}$ \\ ${ }^{1}$ Department of Zoology, University of Washington, Box 351800, Seattle, Washington 98195; and \\ ${ }^{2}$ Houston Museum of Natural Science, 1 Herman Circle Drive, Houston, Texas 77030
}

\begin{abstract}
Although pyramidellid gastropods are a phylogenetically important group of diverse and abundant ectoparasites, little is known about their life histories. Herein, we describe the adult morphology and development of the pyramidellid Odostomia columbiana, which parasitizes the scallops Chlamys hastata and C. rubida in the Northeast Pacific. Anatomically, adult $O$. columbiana resemble other known pyramidellids although they lack the tentacular pads typical of other Odostomia species. Embryonic development is similar to that described for other pyramidellids: cleavage is unequal, gastrulation is partially by invagination, and considerable growth occurs before hatching. However, embryonic and larval development are much slower than for other described species. The planktotrophic larvae hatch after 19 days of intracapsular development and metamorphose about 2 months later. $O$. columbiana veligers have a large black pigmented mantle organ to the right of the midline, a distinct metapodial tentacle, and three or four long bristles that project over the operculum from behind the foot. Observations of newly metamorphosed juveniles suggest that previous disagreements regarding the development of heterostrophy are due to variation in the degree of heterostrophy among species. Our observations also generally corroborate certain scenarios ex-
\end{abstract}

Received 16 August 1996; accepted 17 December 1996.

* Address for correspondence: Committee on Evolutionary Biology, Culver Hall, 1025 E. 57th Street, Chicago, IL 60637; e-mail: rcollin@midway.uchicago.edu

Abbreviations: $\mathrm{PMO}=$ pigmented mantle organ; $\mathrm{bpl}=$ anterior buccal pump; bp 2 = posterior buccal pump; $\mathrm{VCSGL}=$ ventral ciliated strip gland. plaining the evolution of gastropod cleavage type and larval heterochrony. Unequal cleavage and larvae that hatch without well-developed eyes and tentacles may be characteristic of the common ancestor of pyramidellids and opisthobranchs; however, late development of the larval heart is probably a derived condition of opisthobranchs.

\section{Introduction}

Pyramidellids are common ectoparasites in many marine communities, but little is known about their biology and life histories (Haszprunar, 1988; Wise, 1996). In particular, data concerning their development and larval biology are lacking. As in many benthic marine invertebrates with limited adult dispersal, the duration of a planktonic larval stage may be a key factor influencing pyramidellid distribution and population dynamics. Long-lived planktonic stages may increase colonization of patchily distributed hosts, whereas species that hatch as crawling juveniles may have lower probabilities of local extinction (Thorson, 1950; White et al., 1984; Cumming, 1993). Therefore, knowledge of pyramidellid development and larval biology is key to understanding their life histories and host-parasite interactions, and to planning effective pest-control strategies for aquaculture.

Pyramidellid development is also particularly informative when viewed in a phylogenetic context. Generally, pyramidellids are placed, with other families in the order Heterostropha, at the base of the heterobranch clade (Haszprunar, 1988). Although the relationships among these families are poorly resolved, pyramidellids clearly represent basal members of the clade that in- 
cludes opisthobranchs and pulmonates, and which is the sister group of the Caenogastropoda (Haszprunar, 1988; Bieler, 1992; Mikkelsen, 1996). Knowledge of such basal groups can be useful in tracing evolutionary transitions, determining ancestral character states, and testing evolutionary scenarios. This knowledge may be particularly useful in gastropod development, where evidence for evolutionary scenarios is often available from derived representatives of only a few clades. For example, van den Biggelaar (1996) found a trend in cleavage type and Dquadrant specification from equal cleavage and late specification in "archaeogastropods" to unequal cleavage and early specification in opisthobranchs and pulmonates. Additionally, Page (1994) suggested that heterochronic shifts in gastropod development decelerated the formation of larval and adult structures in opisthobranch larvae relative to prosobranchs. These scenarios were generated primarily from observations of derived caenogastropods, opisthobranchs, and pulmonates. Moreover, detailed descriptions of pyramidellid development could be used to further support or refute these types of scenarios.

To date, accounts of pyramidellid reproduction and embryology are brief and limited to a small number of European (Lebour, 1932, 1936; Rasmussen, 1944, 1951; Fretter and Graham, 1949), eastern North American (Robertson, 1978; White et al., 1985), and Indo-Pacific (Amio, 1963; Nishino et al., 1983; Cumming, 1993) species (Table I). Although more than 50 species have been reported from western North America (Dall and Bartsch, 1909), there exists only a single account of pyramidellid development from the region (LaFollette, 1979). No detailed embryological studies of pyramidellids have been published, and larvae that do not metamorphose immediately after hatching are seldom reared through settlement (see Robertson, 1967, for an exception). Consequently, the details of early development, the duration of the planktonic period, and the events at metamorphosis have been the subject of much speculation (Thorson, 1946; Fretter et al., 1982).

Published accounts of pyramidellid reproduction and development are often obscured by taxonomic confusion within the group. Criteria used to identify species are often not explicitly stated in published reports, or the taxonomy is so conjectural that species cannot be identified with much certainty. For example, Clark (1971) and offmann (1979) did not state how they identified their as Odostomia columbiana, and Cumming (1993) able to definitely identify "Turbonilla sp." to gespecies. This taxonomic uncertainty makes it dificesit to interpret comparative reproductive and developmanal data.

Repor of poecilogony, a rare condition in gastropods (Hoaglane and Robertson, 1988; Bouchet, 1989) in which two or more developmental modes occur in one species, may be an example of such taxonomic confusion. Boonea impressa has been reported to have planktotrophic development in North Carolina and lecithotrophic development in Texas. However, these populations may not represent the same species (Bouchet, 1989). Both small eggs that develop into planktotrophic larvae and large eggs with direct development have also been reported for Brachystomia rissoides in areas of different salinities in Europe (Pelseneer, 1914; Rasmussen, 1944, 1951; Thorson, 1946).

This paper adds to the data on pyramidellid development while avoiding the taxonomic confusion of previous studies by describing both the adult morphology and the development of the pyramidellid Odostomia columbiana Dall and Bartsch, 1907. This new information is discussed in the context of the general characteristics of pyramidellid development and its implications for the evolution of development within the gastropods.

\section{Materials and Methods}

Mature Odostomia columbiana were found on the scallops Chlamys hastata and $C$. rubida dredged from $90-130 \mathrm{~m}$ in San Juan Channel, Washington $\left(48^{\circ} 34^{\prime} 10^{\prime \prime} \mathrm{N}, 123^{\circ} 2^{\prime} 0^{\prime \prime} \mathrm{W}\right)$ during March 1995 . Both the snails and their hosts were kept at ambient sea temperature $\left(8^{\circ}-12^{\circ} \mathrm{C}\right)$ in flow-through sea-tables at Friday Harbor Laboratories, Washington. Snails ranged from 5 to $8 \mathrm{~mm}$ in length and were identified as $O$. columbiana on the basis of the original description of the shell provided by Dall and Bartsch (1907) and by comparison with the holotype and five syntypes on deposit at the National Museum of Natural History (lot \#126658). Voucher specimens have been deposited at the Field Museum of Natural History (FMNH 293334: dry shells; FMNH 293334: formalin-fixed animals).

\section{Adult morphology}

Adult snails were extracted for dissection by first cracking their shells with a vise. Snails were dissected whole, and structures of the gut and reproductive tract were routinely stained with toluidine blue (Wise, 1993, 1996).

\section{Development}

Egg masses were present on the scallops when they were collected, and adult snails continued to produce egg masses in the laboratory until May 1996. Scallop shells were checked for new egg masses several times a month to determine whether reproduction was seasonal. Individual egg masses were removed from the scallop shells and kept in small glass dishes while their development 
was observed. Although we did not observe egg laying, several egg masses were collected before the beginning of first cleavage. Observations of these egg masses were used to produce a developmental timetable. Eggs and egg capsules were measured prior to first cleavage, and measurements were taken in the plane of the chalazae. After hatching, larvae were transferred to filtered $(0.45 \mu \mathrm{m})$ seawater in small glass dishes. They were fed Isochrysis galbana and Rhodomonas sp. ad libitum, and the water was changed every 2 to 3 days. Because the larval shells are hydrophobic, flakes of cetyl alcohol were added to the surface of the cultures to prevent larvae from becoming trapped in the surface tension. When the veligers began to spend time crawling, juvenile scallops were added to the cultures to induce metamorphosis and as food for newly metamorphosed juveniles. All observations reported are of animals reared or maintained in the laboratory.

Larval shells were prepared for scanning electron microscopy by rinsing them in dilute bleach and distilled water following the procedure of Hickman (1995). They were mounted on stubs with double-sided tape, coated with gold and palladium, and examined with a JEOL JM35 scanning electron microscope.

\section{Results}

\section{Adult morphology}

The following is given in the concise style of a species description.

Shell: Relatively thin, elongate conical, chalky white, $5-8 \mathrm{~mm}$ in length, composed of 5 to 6 adult whorls. Adult whorls with numerous fine spiral growth lines. Whorl shoulders rounded, with moderately deep sutures. Shell etched and pitted, particularly above body whorl. Lenticular aperture, with flared lower portion. Single, short, acute columellar fold on upper half of columella perpendicular to columellar axis. Smooth, sinistrally heterostrophic protoconch oriented 130 degrees to teleoconch axis, with $40 \%$ submerged within first adult whorl. Operculum brown, lenticular, with subcentric nucleus.

Head-Foot: White to yellow, with numerous scattered white cells. Propodium with slight medial indentation and rounded lateral edges. Foot narrows posterior to propodium, then widening to gradually taper to a blunt apex. Pedal gland opens in middle of groove extending along posterior half of ventral surface of foot. Attachment thread present. Tentacles subtriangular, connate, ventrolaterally folded; tentacular pads apparently absent. Black round eyes beneath epithelium on median side of tentacles. Mentum unnotched, not bifurcate.

Alimentary Tract: Retracted introvert-proboscis extending posteriorly from its aperture on ventral side of head, dorsal to mentum base and entering cephalic

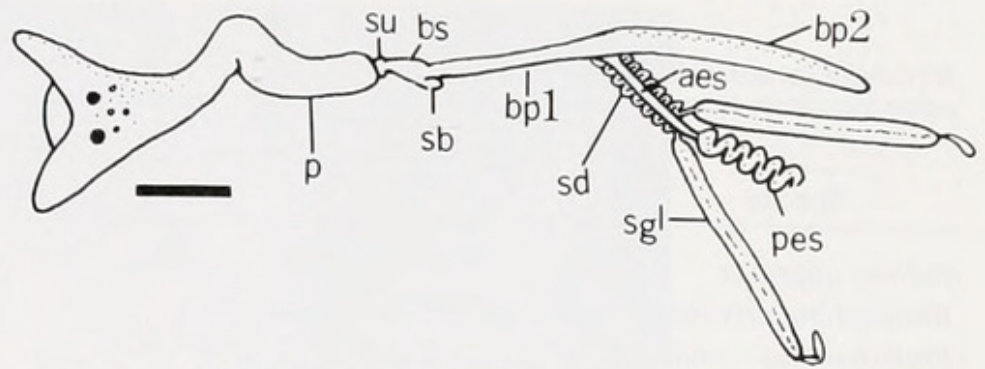

Figure 1. Diagram of alimentary tract of Odostomia columbiana. aes $=$ anterior esophagus, bp $1=$ buccal pump 1 , bp 2 = buccal pump 2 , $\mathrm{bs}=$ buccal sac, $\mathrm{p}=$ proboscis, pes $=$ posterior esophagus, $\mathrm{sb}=$ stylet bulb, $\mathrm{sd}=$ salivary gland duct, $\mathrm{sgl}=$ salivary gland, $\mathrm{su}=$ sucker. Scale bar is $500 \mu \mathrm{m}$

hemocoel (Fig. 1). Introvert joining buccal sac (containing buccal sucker, stylet, and stylet bulb), which is connected to buccal pump. Buccal pump divided into anterior (bp1) and posterior (bp2) sections, with bp2 one-third longer than bp 1 ; bp 1 narrow, round in crosssection; bp2 wider, laterally flattened, distally rounded. Short, straight anterior esophagus originating on ventral surface of alimentary tract at bp 1-bp2 juncture, extending posteriorly to join posterior esophagus and paired salivary glands, forming a four-way junction. Long, highly coiled posterior esophagus extending posteriorly to enter visceral mass and join stomach. Long, narrow salivary glands equal to bp 2 in length. Salivary gland ducts highly folded and attached to anterior esophagus. Ducts penetrating alimentary tract just anterior to bp 1bp2 juncture, extending parallel to one another within walls of $\mathrm{bpl}$ and entering stylet bulb without exiting gut. Salivary glands not attached distally to esophagus.

Pallial Cavity: Mantle and mantle organs typical of members of the Odostominae, with exception of position of ventral ciliated strip gland (=VCSGL). Small, spherical, yellow VCSGL underlying $20 \%$ of ventral ciliated strip about halfway from anterior edge of mantle floor. Ventral and dorsal ciliated strips joining on mantle roof posterior end of mantle cavity. Small, round-to-oblong pigmented mantle organ (=PMO), composed primarily of cells containing a bright yellow exudate, framed by numerous brown cells. A thick, bright yellow exudate is released when snail is disturbed.

Reproductive System: Opaque-to-transparent reproductive organs located on columellar side. Common pallial gonoduct extends anteriorly from visceral mass to open on right side of head just anterior and beneath the right tentacle.

\section{Reproduction and development}

Our observations of reproduction and larval development of $O$. columbiana generally agree with previous accounts of pyramidellid development (Pelseneer, 1914; 
Table I

Review of pyramidellid development

\begin{tabular}{|c|c|c|c|c|c|c|}
\hline Species & $\begin{array}{l}\text { Egg size } \\
(\mu \mathrm{m})\end{array}$ & $\begin{array}{c}\text { Capsule size } \\
(\mu \mathrm{m})\end{array}$ & $\begin{array}{l}\text { Days to } \\
\text { hatching }\end{array}$ & $\begin{array}{l}\text { Larval duration } \\
\qquad \text { (days) }\end{array}$ & $\begin{array}{l}\text { Temp. } \\
\left({ }^{\circ} \mathrm{C}\right)\end{array}$ & Reference \\
\hline Boonea impresat & $130^{*}$ & $180-280^{*}$ & $3-5$ & 7 & $\sim 25$ & White et al., 1985 \\
\hline Brachystomia rissoides & 120 & 500 & 25 & 0 & $?$ & Rasmussen, 1951 \\
\hline Brachystomia rissoides & 60 & 200 & $?$ & $?$ & $?$ & Thorson, 1946 \\
\hline Brachystomia rissoides & 70 & 200 & 6 & $?$ & $\sim 20$ & Rasmussen, 1944 \\
\hline Brachystomia rissoides & 100 & 380 & 25 & 0 & $?$ & Pelseneer, 1914 \\
\hline Chrysallida cincta & $?$ & 320 & $22-27$ & 0 & 20 & LaFollette, 1979 \\
\hline Chrysallida decussata & $90-120 \dagger$ & $240-350$ & $?$ & $?$ & $?$ & Lebour, 1936 \\
\hline Menestho diaphana & $80^{*}$ & 200 & 16 & $?>8$ & 11 & Kristensen, 1970 \\
\hline Odostomia acuta & $\sim 80^{*}$ & $160 \times 200$ & a few & $?$ & $?$ & Høisæter, 1989 \\
\hline Odostomia columbiana & $72-74$ & $153-178$ & 19 & $\sim 70$ & 12 & this study \\
\hline Odostomia desimana & 80 & $130 \times 160$ & 14 & $?$ & $?$ & Amio, 1963 \\
\hline Odostomia eulimoides & $?$ & $?$ & $10-12$ & $3-4$ & 18 & Fretter and Graham, 1949 \\
\hline Odostomia eulimoides & $90^{*}$ & 160 & $?$ & $?$ & $?$ & Lebour, 1932 \\
\hline Odostomia fujitaii & $?$ & $?$ & $15-16$ & $8-12$ & 15 & Minichev, 1971 \\
\hline Odostomia sp. & $\sim 100^{*}$ & $\sim 200^{*}$ & 7 & $3(?)$ & 22 & Nishino et al., 1983 \\
\hline Odostomia omaensis & 60 & $120 \times 150$ & 8 & $?$ & $?$ & Amio, 1963 \\
\hline Turbonilla sp. & 130 & $300 \times 400$ & $10-11$ & $3-5$ or 0 & 23 & Cumming, 1993 \\
\hline
\end{tabular}

* Measured from figures.

† 4-8 eggs per capsule.

Lebour, 1932, 1936; Rasmussen, 1944, 1951; Fretter and Graham, 1949; White et al., 1985). However, both embryonic (used here to refer to development prior to hatching) and larval development are much slower than reported for other species (Tables I and II). Although we searched for spermatophores like those described by Robertson (1978), at no time did we find any attached to the shells or bodies of these snails. Egg masses each containing up to several hundred eggs were deposited on

\section{Table II}

Developmental time table for $\mathrm{O}$. columbiana at $10-12^{\circ} \mathrm{C}$

\begin{tabular}{|c|c|}
\hline Age & Stage \\
\hline$\sim 6 \mathrm{~h}$ & First cleavage \\
\hline $18 \mathrm{~h}$ & 4 cells \\
\hline $24 \mathrm{~h}$ & 8 cells \\
\hline $48 \mathrm{~h}$ & Round blastula \\
\hline $2-3$ days & $\begin{array}{l}\text { Gastrulation: blastula flattens and then forms a } \\
\text { horseshoe-shaped gastrula }\end{array}$ \\
\hline $3-7$ days & Gastrula \\
\hline 8 days & $\begin{array}{l}\text { Foot and head rudiments begin to differentiate, some } \\
\text { trochal ciliary motion; the shell is not yet present }\end{array}$ \\
\hline 10 days & $\begin{array}{l}\text { Shell, cilia, and foot with operculum and statocysts } \\
\text { present, light red PMO just visible }\end{array}$ \\
\hline 17 days & Heartbeat and ciliary motion in gut visible \\
\hline 19 days & Veligers hatch, $\mathrm{PMO}$ is black \\
\hline $72-80$ days & Veligers begin to crawl \\
\hline$\sim 90$ days & Settlement and metamorphosis \\
\hline
\end{tabular}

the hosts' shells continually from March 1995 until May 1996 when the last of the snails died. Irregular egg masses are often deposited in groups, making it difficult to distinguish individual masses. Each snail generally produced several egg masses per week.

Individual eggs are white and range from 71 to $77 \mu \mathrm{m}$ in diameter $($ mean $=74.5 ; \mathrm{SD}=1.61 ; n=23)$. Egg size did not differ between summer (July) and winter (January). Each round egg, surrounded by an oval layer of opaque albumin, is enclosed in a thick transparent gelatinous capsule (Fig. 2A-F). The length of the space enclosing the albumin is $154-170 \mu \mathrm{m}$ (mean $=162.5$; $\mathrm{SD}=4.6 ; n=23$ ) and the outer length of the capsule is $193-222 \mu \mathrm{m}($ mean $=211 ; \mathrm{SD}=6.9 ; n=23)$. In some previous accounts of pyramidellid development (e.g., White et al., 1985), capsular length has been reported as egg size, whereas other studies measure the egg cell. In this paper "egg" is used to denote the actual egg cell, and "capsule" refers to the egg and the albumin contained in one gelatinous covering. The capsules are connected to one another by thin strands called chalazae. In $O$. columbiana, chalazae are composed of a thin extraembryonic layer that surrounds the albumin layer beneath the capsule, traverses the capsule, and continues between capsules as a thin tubular strand (Fig. 2C). The egg, albumin, and capsular covering are embedded in a transparent gelatinous matrix that is often covered with diatoms.

All eggs within a single egg mass develop synchro- 

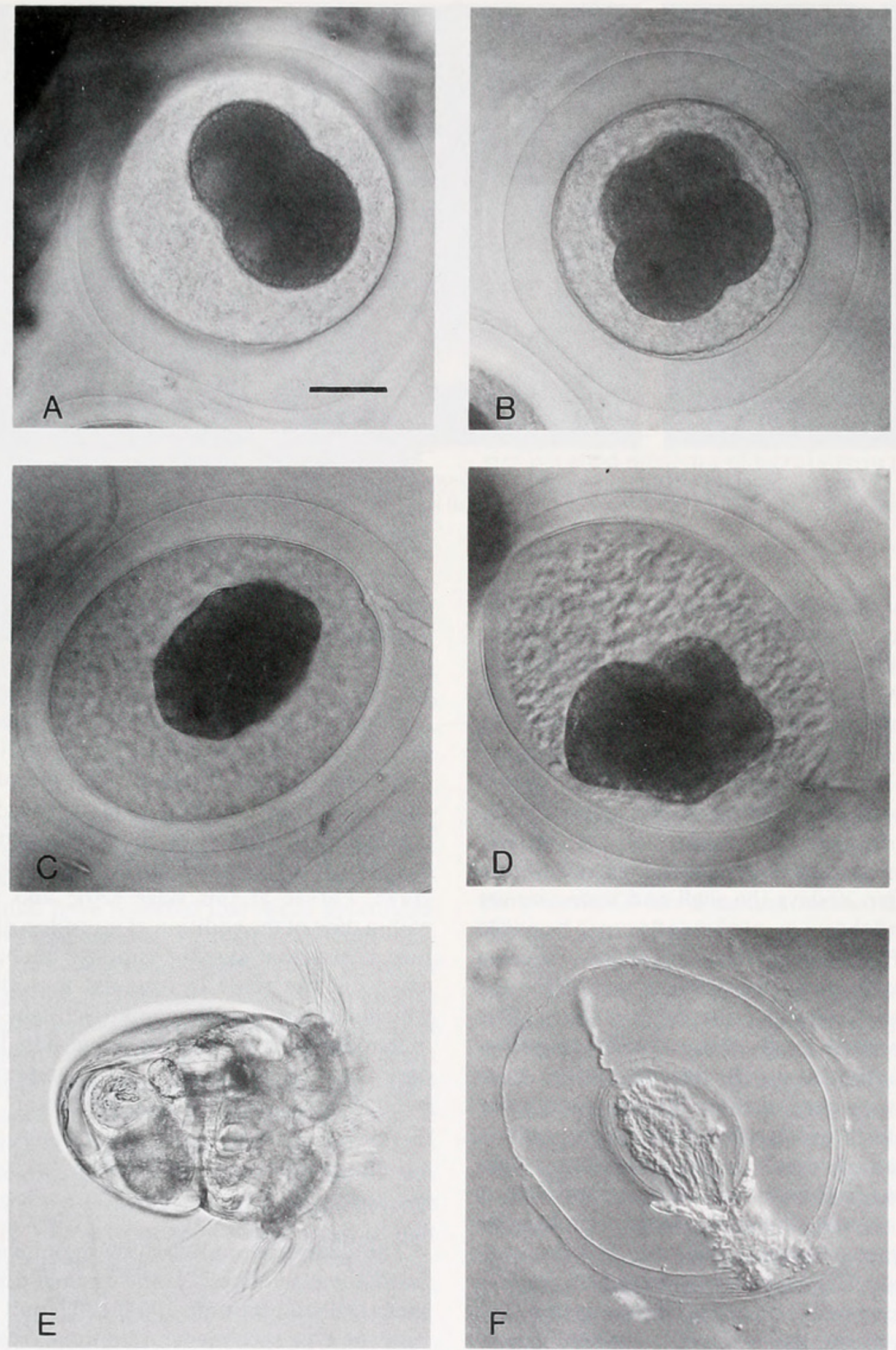

Figure 2. Stages in Odostomia columbiana development. (A) Two-cell stage; (B) four-cell stage; (C) blastula; (D) begining of differentiation of the foot, velum, and shell; (E) hatchling veliger; (F) empty egg capsule. In A and B the capsule appears round because it is viewed end on. Chalazae are clearly visible in the upper right of $\mathrm{C}$ and the upper left of $\mathrm{F}$. All figures are to the same scale, and scale bar is $\mathrm{A}$ is $40 \mu \mathrm{m}$.

nously, and the initial cleavages are simultaneous. First cleavage is clearly unequal (Fig. 2A), but the second cleavage appears to be more-or-less equal. This results in a four-cell stage with two relatively large cells and two small cells (Fig. 2B). Third cleavage is also unequal. Because the polar bodies are initially obscured by the 

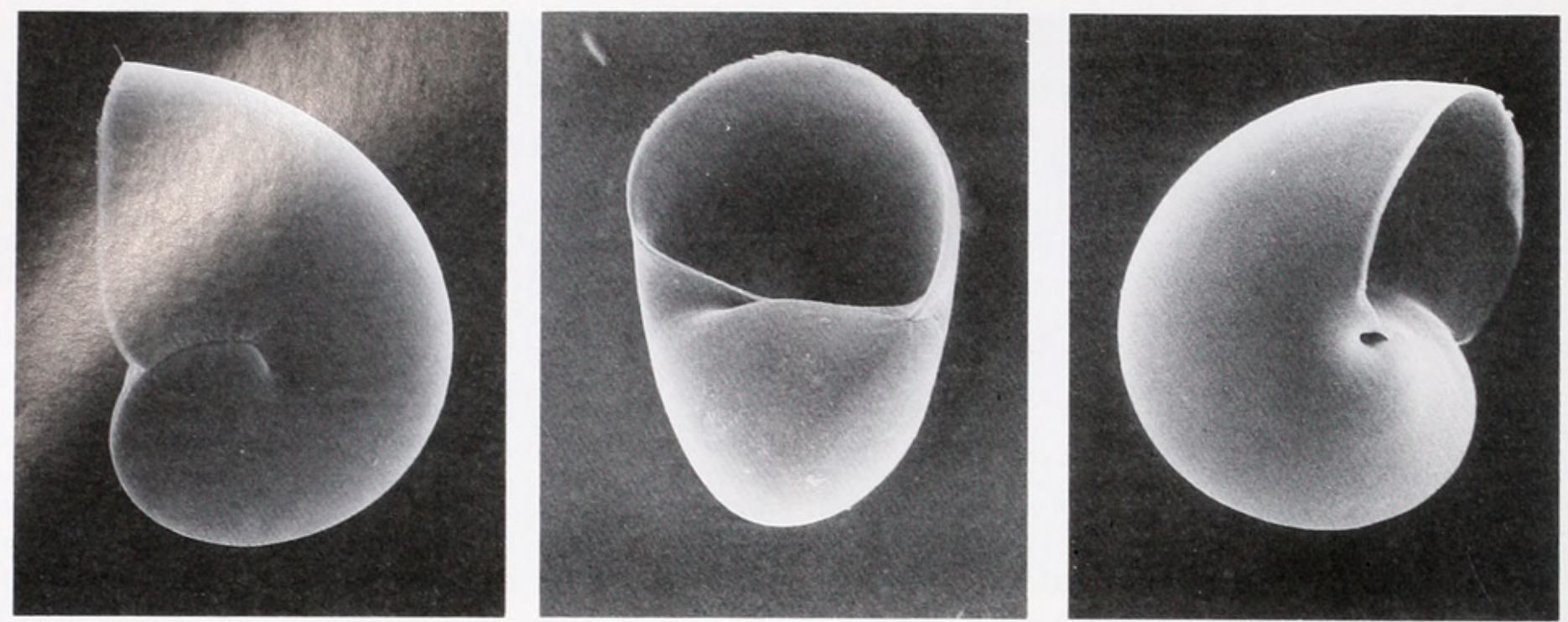

Figure 3. Scanning electron micrograph of Odostomia columbiana larval shell at hatching. Apical, apertural, and umbilical views, from left to right. Shell length is $150-160 \mu \mathrm{m}$ for these three shells.

opaque albumin, the polarity and direction of this division could not be determined.

After 2 days the initially spherical blastula flattens (Fig. 2C) and in the next few days develops into a heartshaped or cup-shaped gastrula. Thus gastrulation occurs at least partially by invagination, as is typical of many opisthobranchs. After 8 days the foot, head, and velum anlangen appear (Fig. 2D), and short cilia present on the velar lobes beat weakly. Even after the cilia are fully formed the embryos rotate very slowly, if at all, within the capsules. After 10 days the shell and statocysts are clearly visible, and the pigmented mantle organ begins to develop. As the PMO grows it darkens and changes from dark red to black before the larvae hatch. At 17 days the beating heart is visible, and the cilia of the gut are active. The embryo continues to absorb the surrounding albumin and grows until it eventually fills the capsule. At no time during development did we observe paired larval kidneys similar to those described by Pelseneer (1914). Additionally, methods used to demonstrate protein uptake in morphologically similar caenogastropod larval kidneys (Collin, unpubl. data) did not detect protein uptake in decapsulated embryos. Inspection of capsules, after hatching, shows that larvae hatch through an opening in the capsule along one of the chalazal strands (Fig. 2F).

At hatching the smooth, sinistral protoconch comprises nearly an entire whorl (Fig. 3) and is $150-160 \mu \mathrm{m}$ in length $(n=7$; Fig. 3$)$. Newly hatched larvae have a black PMO just to the right of the midline, a small bilobed velum, and no eyes, tentacles, or obvious apical tuft (Fig. 2E). Except for the PMO and the stomach and digestive gland, whose color reflects larval diet, the veliger is entirely transparent. Although larvae retracted into their shells when placed under the microscope, the foot points slightly to the animal's right when they swim. As the foot grows, the metapodial tentacle, the posterior protuberance of the foot (distinct from adult metapodial tentacles) and its terminal cilia, which extend over the operculum, become more obvious. On each side of the foot, three or four bristles, which seem to originate behind the foot, project radially over the edge of the operculum. Veligers develop eyes within 18-23 days of hatching. After 2 months, the velum shrinks and the larvae, which are about $290 \mu \mathrm{m}$ in shell length, begin to crawl. Larvae at this stage settle and metamorphose within days of the addition of juvenile scallops to the culture. Larvae that were the same age but had not begun to crawl did not settle in response to scallops. Water in which scallops had been kept overnight did not induce metamorphosis in crawling larvae. The PMO remained dark for at least 1 month after metamorphosis (Fig. 4), but had turned yellow after 6 months.

\section{Discussion}

\section{Taxonomic note}

The snails used in this study were identified as $O$. columbiana on the basis of the original description of the shell (Dall and Bartsch, 1907, 1909) and by comparison with the type specimens. All animals were collected attached to Chlamys spp. However, previous papers have described $O$. columbiana found on Trichotropis cancellata in Puget Sound, but did not state how the snails were identified (Clark, 1971; Hoffmann, 1979). Pyramidellid snails on $T$. cancellata are much smaller (2-4 mm, pers. obs., RC) than the snails used in this study and those described by Dall and Bartsch (up to $8 \mathrm{~mm}$ ). The differences in size and host suggest that these may be two 


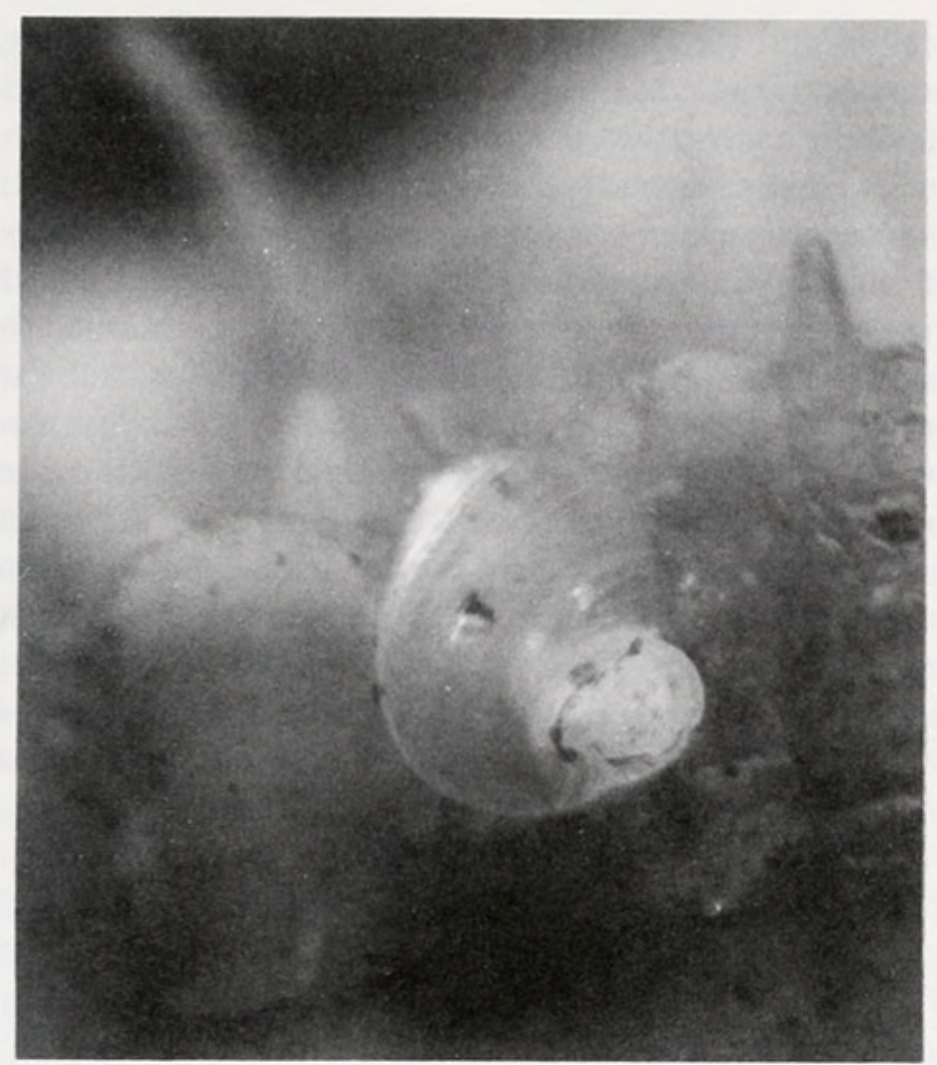

Figure 4. Juvenile Odostomia columbiana at the edge of a scallop shell about 1 month after settlement. The black PMO is visible through the shell in the middle of the body whorl. Shell length is about $700 \mu \mathrm{m}$.

different species. Nevertheless, the adult shell shape, sculpture, protoconch morphology, and adult anatomy are quite similar.

Previous studies have reported that some pyramidellids may not be host specific, or their preference may change as they grow (Boss and Merrill, 1965; Powell et al., 1987), suggesting that the association of small animals with $T$. cancellata and large animals with Chlamys spp. may represent an ontogenetic host shift. This is unlikely because juvenile $O$. columbiana raised in this study did not move onto $T$. cancellata when given the choice between juveniles of Chlamys spp. or $T$. cancellata. No egg masses were discovered on $T$. cancellata, so it is unclear whether the pyramidellids from these hosts were sexually mature. Our preliminary results suggest that these are closely related species.

\section{Adult morphology}

The morphology of $O$. columbiana is very similar to that of other members of the family. However, it differs in several ways from the morphology of known species of the genus Odostomia. Odostomia columbiana lacks tentacular pads, and its gut arrangement is similar to that found in members of the genus Boonea except that the salivary gland ducts are attached to the anterior esophagus, which with the posterior esophagus and paired sali- vary glands form a four-way junction (Fig. 1). Odostomia columbiana, as well as other members of the subfamily Odostominae, will ultimately be relegated to other genera (Wise, in prep.).

\section{Pyramidellid development}

The reproduction and development of $O$. columbiana is similar to that previously described for other pyramidellids (Lebour, 1932, 1936; Rasmussen, 1944, 1951; Fretter and Graham, 1949; White et al., 1985), although most of these descriptions are brief and small differences may have been overlooked. Eggs of $O$. columbiana are relatively small, but not unusually so (Table I). Because embryos grow to fill the capsule before hatching, capsule size is a good predictor of larval size in pyramidellids. $O$. columbiana deposits a single egg per capsule, as do other pyramidellids except Chrysallida decussata (Table I). Development of $O$. columbiana is slower than in other species with comparable egg size; only species with large eggs and direct development have a similarly long embryonic period (Table I). Because water temperatures were either not reported or varied considerably in several previous studies, it is difficult to determine whether these differences in development rate were due to temperature.

In $O$. columbiana the long embryonic period is followed by an unusually long planktonic larval stage. Although times to metamorphosis may be different in the laboratory than in nature, veligers in two non-overlapping cultures settled at the same age. Furthermore, recent improvements in larval culture technique and larval diet have reduced the time to metamorphosis in cultures of other invertebrate larvae (Strathmann, 1987). This suggests that the longer larval period of $O$. columbiana in comparison to other laboratory-reared pyramidellid species from previous studies is real (Table I). Unfortunately these studies did not indicate if the larvae studied were planktotrophic or if food was added to the larval cultures. A distinctive characteristic of the $O$. columbiana veligers is the presence of bristles extending over the operculum from the side of the foot. These are not figured or mentioned in any other description of pyramidellid larvae.

Our observations increase the data on the distribution of several developmental characters that are used in heterobranch systematics. Robertson (1985) suggested that chalazae may be a useful synapomorphy shared by pyramidellids, architectonicids, and opisthobranchs. Chalazae are clearly present in egg masses of $O$. columbiana and many other pyramidellids. Høisæter (1989), however, suggests that some pyramidellids lack chalazae and that their presence may be a useful systematic character within the pyramidellids. He did not find chalazae in $O$. acuta, and they were not mentioned in descriptions of egg masses from Brachystomia eulimoides (Lebour, 
1932) and Odostomia sp. (Nishino et al., 1983). Additionally, the shape and thickness of the chalazae of $O$. fujitanii figured by Minichev (1971) are clearly different from those in $O$. columbiana and other pyramidellids. Spermatophores have also been used as a systematic character within pyramidellids to define the genus Boonea (Robertson, 1978). O. columbiana apparently lacks spermatophores; however, this character has been observed in some other species occurring in the northeastern Pacific (A. J. Kohn, pers. comm.).

Our observations of pyramidellid development from hatching to metamorphosis illuminate several points that have been the subject of much conjecture. At hatching, veligers of $O$. columbiana are morphologically similar to veligers of other planktotrophic pyramidellid species, all of which seem to have small, nonpigmented velums. Previous studies that failed to rear larvae to metamorphosis often concluded that the larval period is short because the velum is small (e.g., Thorson, 1946). This is not the case for $O$. columbiana, which has a long planktonic period during which its velum remains small. Small velar lobes are also typical of planktotrophic opisthobranch larvae (pers. obs., RC), although caenogastropods with long-lived feeding larvae often have large complex velar lobes (Thorson, 1946).

Confusion exists as to how differential shell growth around the aperture results in heterostrophy (the change of coiling direction from a left-handed protoconch to a right-handed teleoconch). Thorson (1946) illustrated several pyramidellid shells near metamorphosis and stated that the outer apertural margin of the larval shell thickens to become a new columella at metamorphosis. Fretter et al. (1982) disagreed and suggested that the protoconch's outer lip is continuous with the outer lip of the teleoconch. In $O$. columbiana, the position of the columella shifts clockwise around the aperture as the coiling direction changes, but not to the extent described by Thorson (1946). These conflicting observations of changes in shell shape at metamorphosis may be due to variation in degree of heterostrophy among pyramidellid species. Although the coiling direction reverses in all cases, the is considerable variation in the displacement of the coils sx is of the teleoconch relative to that of the protoconch. most of the species figured by Thorson (1946), the pros onch is offset roughly perpendicular to the teleoconch. However, in $O$. columbiana and Brachystomia eulmoides (one species studied by Fretter Graham, 1949), the angle between the coiling axes of the protoconch and teleoconch often appears to be closer 140 degrees (Fretter et al., 1982).

\section{Evolutio of gastropod development}

Detaiicd studies of embryology and larvae of "archaeogastropods, "caenogastropods, and opisthobranchs re- veal several trends in gastropod development. Among gastropods there is a trend in both caenogastropods and opisthobranchs toward unequal cleavage and early Dquadrant specification (Freeman and Lundelius, 1992; van den Biggelaar, 1996; van den Biggelaar and Haszprunar, 1996). Equal cleavage with $4 d$ cell formation at the 64-cell stage as in "archaeogastropods" is assumed to be the ancestral condition. In opisthobranchs, the first one or two cleavages are unequal, and the $4 \mathrm{~d}$ cell is produced by the 24-cell stage. Intermediate conditions occur in the Architaenioglossa and the Valvatoidea, and there is considerable variation in basal opisthobranchs (van den Biggelaar, 1996). Although Pelseneer (1914) and van den Biggelaar and Haszprunar (1996, citing Pelseneer) report equal cleavage in pyramidellids, first cleavage in $O$. columbiana is clearly not equal. In addition, White et al. (1985) figured an unequal two-cell stage of Boonea impressa in the process of division. This suggests that either cleavage varies among pyramidellids (an unusual occurrence in gastropod groups) or Pelseneer's account is inaccurate. Regardless, it is interesting that early cleavage divisions in pyramidellids are similar to those in anaspideans and some other opisthobranchs.

Page (1994) suggested that heterochronic shifts in the timing of development of larval and adult organs account for some of the variation in gastropod larval development. In "archaeogastropods" the adult organs develop directly from the embryo, whereas in caenogastropods the larva hatches with well-formed larval organs and subsequently develops the definitive adult structures. Development is retarded in opisthobranchs, and they hatch at a stage of morphogenesis similar to that of unhatched caenogastropods: some larval organs develop after hatching, and the definitive adult organs develop during late larval life or at metamorphosis (Page, 1994). Page (1994) paid particular attention to the stage of formation of the eyes, tentacles, and larval heart. Caenogastropod veligers hatch with well-formed eyes and tentacles, and the larval heart develops long before hatching (Page, 1994, and pers. obs). In opisthobranchs, the larvae hatch before the eyes or tentacles have formed, and the larval heart usually forms during the last half of the planktonic stage (Page, 1994). The observations of $O$. columbiana reported here suggest that pyramidellid larval development may combine characters of opisthobranch and caenogastropod development. As in opisthobranchs, the eyes and tentacles did not appear until well into larval development; as in caenogastropods, the heart began to beat well before hatching.

These observations support recognized trends in the evolution of gastropod development and suggest ancestral character states. Unequal cleavage is characteristic of pyramidellids and some basal opisthobranchs, whereas caenogastropods have a polar lobe; thus unequal cleav- 
age may be a heterobranch synapomorphy. However, additional groups at the base of this clade must be examined to rule out parallel evolution of unequal cleavage from an equally cleaving ancestor, because many other opisthobranchs and pulmonates have equal cleavage. Additionally, larvae that hatch before the development of eyes and tentacles were probably ancestral for pyramidellids and opisthobranchs. On the other hand, early appearance of the larval heart relative to hatching in pyramidellids and caenogastropods suggests that late development of the heart is a derived feature of the opisthobranchs. It is clearly necessary to have detailed descriptions of more phylogenetically intermediate groups and to formulate robust phylogenetic hypotheses before any firm conclusions regarding the evolution of these characters can be drawn.

\section{Acknowledgments}

We thank A. Kabat (US National Museum of Natural History) for lending us the type specimens of $O$. columbiana, R. Bieler (Field Museum of Natural History, Chicago) for accepting the voucher specimens, E. Kozloff for translating Minichev (1971), and D. Willows and the staff of Friday Harbor Laboratories for their support. B. Pernet and R. Strathmann made useful comments on the manuscript. This research was supported by a National Science Foundation Graduate Fellowship and a Pacific Northwest Shell Club Scholarship to RC, and grant OCE 9301665 to R. Strathmann.

\section{Literature Cited}

Amio, M. 1963. A comparative embryology of marine gastropods, with ecological considerations. Shimonoskei Univ. Fish. J. 12: 15144.

Bieler, R. 1992. Gastropod phylogeny and systematics. Annu. Rev Ecol. Syst. 23: 311-338.

Biggelaar, J. A. M. van den. 1996. The significance of the early cleavage pattern for the reconstruction of gastropod phylogeny. Pp. 155160 in Origin and Evolutionary Radiation of the Mollusca, J. D Taylor, ed. Oxford University Press, Oxford, UK.

Biggelaar, J. A. M. van den, and G. Haszprunar. 1996. Cleavage and mesentoblast formation in the Gastropoda: an evolutionary perspective. Evolution 50: 1520-1540.

Boss, K. J., and A. S. Merrill. 1965. Degree of host specificity in two species of Odostomia (Pyramidellidae: Gastropoda). Proc. Malacol. Soc. London 36: 349-355.

Bouchet, P. 1989. A review of poecilogony in gastropods. J. Moll Stud. 55: 67-78

Clark, K. 1971. Host texture preference of an ectoparasitic opisthobranch, Odostomia columbiana Dall and Bartsch 1909. Veliger 14: $54-56$

Cumming, R. L. 1993. Reproduction and variable larval development of an ectoparasitic snail, Turbonilla sp. (Pyramidellidae, Opisthobranchia) on cultured giant clams. Bull. Mar. Sci. 52: 760-771.

Dall, W. H., and P. Bartsch. 1907. The pyramidellid mollusks of the
Oregonian faunal area. Proc. U. S. Natl. Mus. 33: 491-534.

Dall, W. H., and P. Bartsch. 1909. A monograph of west American pyramidellid mollusks. Bull. U. S. Natl. Mus. 68: 1-258.

Freeman, G., and J. W. Lundelius. 1992. Evolutionary implications of the mode of D quadrant specification in coelomates with spiral cleavage. J. Evol. Biol. 5: 205-247.

Fretter, V. M., and A. Graham. 1949. The structure and mode of life of the Pyramidellidae, parasitic opisthobranchs. J. Mar. Biol. Assoc. U.K. 28: 493-532.

Fretter, V. M., A. Graham, and E. B. Andews. 1982. The prosobranch molluscs of Britain and Denmark. Part 9-Pyramidellidae. J. Moll. Stud. Suppl. 11: 363-434.

Haszprunar, G. 1988. On the origin and evolution of major gastropod groups, with special reference to the Streptoneura. J. Moll. Stud. 54: $367-441$

Hickman, C. S. 1995. Asynchronous construction of the protoconch/ teleoconch boundary: evidence for staged metamorphosis in a marine gastropod larva. Invertebr. Biol. 114: 295-306.

Hoagland, K. E., and R. Robertson. 1988. An assessment of poecilogony in marine invertebrates: phenomenon or fantasy? Biol. Bull. 174: $109-125$.

Hoffmann, D. L. 1979. An attachment structure in an epiparasitic gastropod. Veliger 22: 75-77.

Høisæter, T. 1989. Biological notes on some Pyramidellidae (Gastropoda: Opisthobranchia) from Norway. Sarsia 74: 283-297.

Kristensen, J. H. 1970. Fauna associated with the sipunculid Phascolion strombi (Montagu), especially the parasitic gastropod Menestho diaphana (Jeffreys). Ophelia 7: 257-276.

LaFollette, P. 1979. Observation on the larval development and behavior of Chrysallida Carpenter, 1857 (Gastropoda: Pyramidellidae). West. Soc. Malacol. Annu. Rep. 10: 18-23

Lebour, M. 1932. The eggs and early larvae of two commensal gastropods, Stilifer stylifer and Odostomia eulimoides. J. Mar. Biol. Assoc. U.K. 18: 117-119

Lebour, M. 1936. Notes on the eggs and larvae of some Plymouth prosobranchs. J. Mar. Biol. Assoc. U.K. 20: 547-566.

Mikkelsen, P. M. 1996. The evolutionary relationships of Cephalaspidea s.l. (Gastropoda: Opisthobranchia): a phylogenetic analysis. Malacologia 37: 375-442.

Minichev, Y.S. 1971. On the biology of some Pyramidellidae of the Possjet Bay of the Sea of Japan. Acad. Sci. USSR Zool. Inst. Explorations of the Fauna of the Seas 8: 221-229 [in Russian].

Nishino, T., S. Nojima, and T. Kikuchi. 1983. Quantitative studies of life history and interspecific relationship of two gastropod species, Odostomia sp. (ectoparasite) and Umbonium (Suchium) moniliferum (Lamarck) (host). I. Life history and population dynamics of Odostomia sp. Publ. Amakusa Mar. Biol. Lab. Kyushu Univ. 7: 6167

Page, L. R. 1994. The ancestral gastropod larval form is best approximated by hatching-stage opisthobranch larvae: evidence from comparative developmental studies. Pp. 206-223 in Reproduction and Development of Marine Invertebrates, W. H. Wilson, S. A. Stricker, and G. L. Shinn, eds. Johns Hopkins University Press, Baltimore, MD.

Pelseneer, P. 1914. Ethologie de quelques Odostomia et d'un Monstrillide parasite de l'un d'eux. Bull. Sci. France Belg. 7: 1-14.

Powell, E. N., M. E. White, E. A. Wilson, and S. M. Ray. 1987. Change in host preference with age in the ectoparasitic pyramidellid snail Boonea impressa (Say). J. Moll. Stud. 53: 285-286.

Rasmussen, E. 1944. Faunistic and biological notes on marine invertebrates. I. The eggs and larvae of Brachystomia rissoides (Hanl.), Eulimella natidissima (Mont.), Retusa truncata (Brug.), and Embletonia pallida (Alder and Hancock). (Gastropoda marina). Vi- 
densk. Medd. Dan. Naturhist. Foren. 107: 207-233.

Rasmussen, E. 1951. Faunistic and biological notes on marine invertebrates II. The eggs and larvae of some Danish marine gastropods. Vidensk. Medd. Dan. Naturhist. Foren. 113: 201-249.

Robertson, R. 1967. The life history of Odostomia bisuturalis, and Odostomia spermatophores (Gastropoda: Pyramidellidae). Year Book Am. Philos. Soc. 1966: 368-370.

Robertson, R. 1978. Spermatophores of six eastern North American pyramidellid gastropods and their systematic significance (with the new genus Boonea). Biol. Bull. 155: 360-382.

Robertson, R. 1985. Four characters and the higher category systematics of gastropods. Am. Malacol. Bull. Spec. Ed. 1: 1-22.

Strathmann, M. F. 1987. Reproduction and Development of Marine Invertebrates of the Northern Pacific Coast. University of Washington Press, Seattle, WA. 670 pp.

Thorson, G. 1946. Reproduction and larval development of Danish marine bottom invertebrates with special reference to the plank- tonic larvae in the Sound (Oresund). Medd. Dan. Fisk-Havunders. Ser. Plancton 4: 1-523.

Thorson, G. 1950. Reproductive and larval ecology of marine bottom invertebrates. Biol. Rev. 25: 1-45.

White, M. E., E. N. Powell, and C. L. Kitting. 1984. The ectoparasitic gastropod Boonea (=Odostomia) impressa: population ecology and the influence of parasitism on oyster growth rates. Mar. Ecol. 5: 283-299

White, M. E., C. L. Kitting, and E. N. Powell. 1985. Aspects of reproduction, larval development, and morphometrics in the pyramidellid Boonea impressa (=Odostomia impressa) (Gastropoda: Opisthobranchia). Veliger 28: 37-51.

Wise, J. B. 1993. Anatomy and functional morphology of the feeding structures of the ectoparasitic gastropod Boonea impressa (Pyramidellidae). Malacologia 35: 119-134.

Wise, J. B. 1996. Morphology and phylogenetic relationships of certain pyramidellid taxa (Heterobranchia). Malacologia 37: 443-511. 

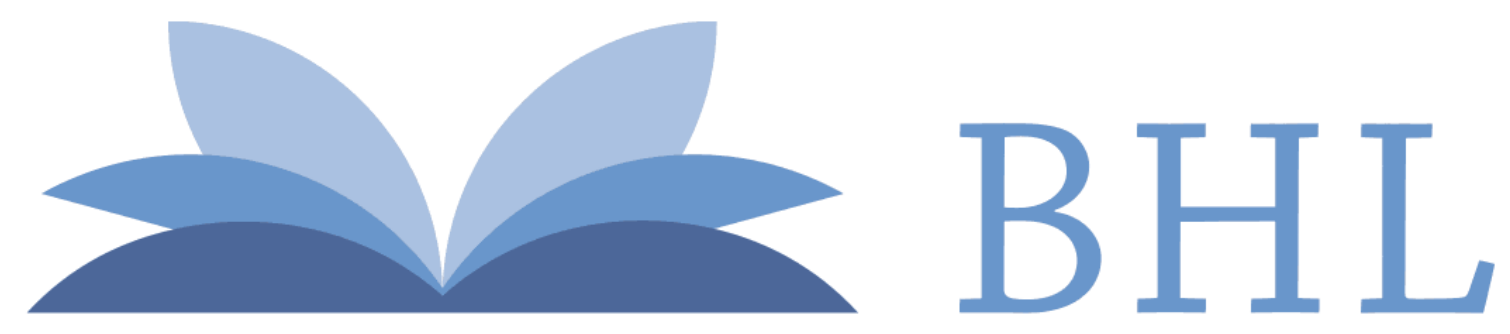

\section{Biodiversity Heritage Library}

Collin, Rachel and Wise, John B. 1997. "Morphology and Development of Odostomia columbiana Dall and Bartsch (Pyramidellidae): Implications for the Evolution of Gastropod Development." The Biological bulletin 192, 243-252. https://doi.org/10.2307/1542718.

View This Item Online: $\underline{\text { https://www.biodiversitylibrary.org/item/17361 }}$

DOI: https://doi.org/10.2307/1542718

Permalink: https://www.biodiversitylibrary.org/partpdf/32083

\section{Holding Institution}

MBLWHOI Library

\section{Sponsored by}

MBLWHOI Library

\section{Copyright \& Reuse}

Copyright Status: In copyright. Digitized with the permission of the rights holder.

License: http://creativecommons.org/licenses/by-nc-sa/3.0/

Rights: https://biodiversitylibrary.org/permissions

This document was created from content at the Biodiversity Heritage Library, the world's largest open access digital library for biodiversity literature and archives. Visit BHL at https://www.biodiversitylibrary.org. 